Session 2665

\title{
Introducing Engineering Concepts into the Early Algebra Classroom
}

\author{
Anne Spence, Taryn Bayles, Claudia Morrell \\ University of Maryland - Baltimore County \\ Baltimore, Maryland
}

\section{INTRODUCTION}

The Introduction to Engineering through Mathematics project seeks to provide algebra students with a link between mathematics and engineering. While most students see the application of algebra to determining how many apples can be purchased at the store with the money in their pocket, they are often unaware that the same types of mathematics can be applied to determine the speed at which an aircraft needs to fly in order to stay aloft. By making these connections for the students, the program seeks to make students aware and excited about the field of engineering. Unfortunately, most students will not be exposed to the field of engineering unless they are involved in an upper level physics or technology class. Since algebra is a required course in many states, this presents a most inviting field in which to plant the seeds of engineering. While algebra provides an opportunity to plant the seed of engineering in all students, it seems logical that this same seed can be encouraged to grow through engineering examples in geometry, trigonometry, and other upper level mathematics courses.

The goal of this project, sponsored by the National Science Foundation, is to increase student enrollment and student diversity in college engineering programs throughout the state of Maryland and, potentially, throughout the country. The program incorporates five objectives in order to attain this goal: (1) develop CD curriculum kits that target different fields of engineering (chemical, electrical, civil, and mechanical) that can be used in both middle and high school algebra classes; (2) provide a summer workshop for in-service mathematics teachers and undergraduate engineering Teaching Fellows; (3) develop an undergraduate engineering Teaching Fellows program to provide hands-on instructional classroom support for middle and high school algebra teachers to help them integrate the CD curricula into their courses; (4) maintain student interest in engineering at schools through the development and institutionalization of an after-school engineering program that culminates in a series of collaborative and competitive activities; and (5) increase the involvement of females and other underrepresented groups in engineering by providing female and minority engineering role models in the classroom and developing curricula that encourage interest and participation by all groups. This paper presents preliminary results of the development of the fluid mechanics and electricity CDs.

"Proceedings of the 2003 American Society for Engineering Education Annual Conference \& Exposition Copyright $(\mathrm{C}$ 2003, American Society for Engineering Education" 


\section{MOTIVATION FOR THE PROJECT}

While the number of science and engineering jobs is projected to grow modestly in the next decade, fewer students are choosing to enroll in engineering programs. ${ }^{1}$ In order to recruit more students, they must be made aware of the benefits and opportunities that an engineering profession would provide. Second, they must take challenging upper level math and science courses necessary to prepare students for college programs. The need to increase both the awareness of and interest in career opportunities in engineering can be addressed, in part, by developing supplemental algebra curricula that use engineering applications to build students' mathematical skills and understanding. These applications will be sensitive to the interests of females and other underrepresented groups and will generate enhanced awareness among all students.

Much can be learned from the successful collaboration between the Tufts [no apostrophe] Center for Engineering Educational Outreach and the Massachusetts Department of Education. ${ }^{2}$ While Massachusetts is much further along in their integration of engineering into the classroom, there are lessons to be learned in their program development that will benefit this project. Another mathematics related project, Adventure Engineering, uses engineering-based curricula in middle grade science and mathematics classes. ${ }^{3}$ The Adventure Engineering project focuses on problem solving and the engineering design experience. A third project uses bridge design software to motivate middle school students to consider future careers in engineering. ${ }^{4}$ This one-day middle school program included presentations from professional engineers and discussions of fundamental engineering concepts.

Yet there is also new ground to break. Adding new engineering courses to the curriculum is a luxury that many school systems can not afford. With the addition of so many new basic requirements for middle and high school students, it became apparent that the best way to impact students would be through the existing curriculum. Algebra is a perfect companion to engineering.

\section{PROJECT DEFINITION}

\section{Development}

The key to the project is the development and evaluation of the engineering/algebra CDs. CDs were selected as the medium for the development and dissemination of curricula for this project because of their ability to be easily replicated and disseminated. Project materials, such as magnets and copper wires, will be packaged as part of a kit, but could easily be assembled by the teacher if needed. A team of college faculty and middle/high school teachers are working together to develop the $\mathrm{CD}$ kits that will provide simple hands-on experiments that allow students to make observations about physical phenomena that can then be explained mathematically. The engineering applications in these CD kits will relate to Maryland State high school requirements for instruction in algebra/data analysis and will be easily usable by algebra teachers. Further, the curricula supports a Maryland state initiative that will require all Maryland students to pass a high school assessment in algebra/data analysis in order to graduate from high school beginning in 2003.

\footnotetext{
"Proceedings of the 2003 American Society for Engineering Education Annual Conference \& Exposition Copyright $₫$ 2003, American Society for Engineering Education"
} 
Each CD kit will be designed to be used in Algebra I classes, which are taught in both middle and high school. These materials will be challenging yet fun and interesting for both groups of students. The CDs will correlate to the expected algebraic knowledge of students at the end of each of the four nine-week sessions that compose the public school academic year. Materials will cover five class periods but will be modifiable for gifted or developmental classes and adaptable for the varying class lengths experienced in middle and high school. All curricula will address the required content standards for algebra/data analysis for the state of Maryland, focusing specifically on 6.0 through 10.0, the more challenging standards shown below.

\begin{tabular}{|c|c|c|}
\hline Standard & Content & CD application \\
\hline $\begin{array}{l}\text { Knowledge of } \\
\text { Number } \\
\text { Relationships } \\
\text { and Computation } \\
(6.0)\end{array}$ & $\begin{array}{l}\text { Students will describe, } \\
\text { represent, and apply numbers } \\
\text { and their relationships and will } \\
\text { estimate and compute using } \\
\text { mental strategies, paper/pencil, } \\
\text { and technology. }\end{array}$ & $\begin{array}{l}\text { Students will be able to demonstrate a } \\
\text { knowledge of number relationships and } \\
\text { computation in conjunction with the } \\
\text { process standards: problem solving, } \\
\text { communication, reasoning, and } \\
\text { connections. }\end{array}$ \\
\hline $\begin{array}{l}\text { Process of } \\
\text { Problem Solving } \\
\text { (7.0) }\end{array}$ & $\begin{array}{l}\text { Students will demonstrate their } \\
\text { ability to apply a wide variety of } \\
\text { mathematical concepts, } \\
\text { processes, and skills to solve a } \\
\text { broad range of problems. }\end{array}$ & $\begin{array}{l}\text { Students will be asked to apply simple } \\
\text { and complex computations to } \\
\text { challenging, thought provoking } \\
\text { questions, speculations, investigations } \\
\text { and explorations. }\end{array}$ \\
\hline $\begin{array}{l}\text { Process of } \\
\text { Communication } \\
(8.0)\end{array}$ & $\begin{array}{l}\text { Students will demonstrate their } \\
\text { ability to organize and } \\
\text { consolidate their mathematical } \\
\text { thinking in order to analyze and } \\
\text { use information, and will } \\
\text { present ideas with words, } \\
\text { symbols, visual displays, and } \\
\text { technology. }\end{array}$ & $\begin{array}{l}\text { Communication plays an important role } \\
\text { in helping students make the connections } \\
\text { between previously learned and newly } \\
\text { acquired knowledge. Explaining, } \\
\text { justifying, predicting, and defending } \\
\text { ideas orally and in writing can clarify } \\
\text { understanding of concepts and principles } \\
\text { and can provide opportunities to assess } \\
\text { understanding and thinking. }\end{array}$ \\
\hline $\begin{array}{l}\text { Process of } \\
\text { Reasoning (9.0) }\end{array}$ & $\begin{array}{l}\text { Students will demonstrate their } \\
\text { ability to reason } \\
\text { mathematically, using inductive } \\
\text { and deductive reasoning and } \\
\text { understand the difference. } \\
\text { Students will justify and draw } \\
\text { conclusions. }\end{array}$ & $\begin{array}{l}\text { Reasoning, analyzing and thinking } \\
\text { logically are essential to knowing and } \\
\text { doing mathematics. Constructing valid } \\
\text { arguments in problem settings and } \\
\text { evaluating the arguments of others are } \\
\text { important skills to be developed over } \\
\text { time through a variety of experiences. } \\
\text { Working in small groups will build } \\
\text { teamwork and require communication } \\
\text { and openness to new ideas. }\end{array}$ \\
\hline $\begin{array}{l}\text { Process of } \\
\text { Connections } \\
(10.0)\end{array}$ & $\begin{array}{l}\text { Students will demonstrate their } \\
\text { ability to relate and apply } \\
\text { mathematics within the } \\
\text { discipline, to other content } \\
\text { areas, and to daily life. }\end{array}$ & $\begin{array}{l}\text { Connections help students view } \\
\text { mathematics as an integrated whole } \\
\text { rather than an isolated set of topics. } \\
\text { Building connections with engineering } \\
\text { will help students acknowledge the } \\
\text { relevance of mathematics, both in and out }\end{array}$ \\
\hline
\end{tabular}

"Proceedings of the 2003 American Society for Engineering Education Annual Conference \& Exposition Copyright (C) 2003, American Society for Engineering Education” 


\begin{tabular}{|l|l|}
\hline & $\begin{array}{l}\text { of school. Acknowledging the } \\
\text { contributions of men and women from } \\
\text { diverse cultures to the engineering field } \\
\text { will also help to break down social } \\
\text { barriers to involvement in engineering. }\end{array}$ \\
\hline
\end{tabular}

As an example, the Electricity and Stored Energy CD kit would begin with a discussion of electricity, followed by a number of simple hands-on experiments taught by undergraduate Teaching Fellows. All applications would focus on materials or situations experienced by students in their daily lives. Research indicates that this connection is particularly important in generating the interest of girls and women. An example follows.

- Begin the session with asking the students to think about how often they watch television, switch on lights, and use telephones. These things, and many others, work using electricity. Ask the students to discuss how different things work. [Possible questions would include: Why does a light bulb light up when you switch it on? How does a cassette recorder work? What makes the picture on your television? How does a radio program get to your radio? How does the sound of someone's voice reach you over the telephone? What makes a compass needle move? What have magnets got to do with electricity? How does a microwave oven work? How does a computer work, a CD player? How does electricity get from a power station to your home? What are batteries? etc.]

- Have the students begin the experiments by playing with magnets. Draw a maze on a piece of cardboard and challenge the students to guide a paperclip through the maze with a magnet. Challenge them to rescue a paper clip from a glass of water without getting wet. Ask them if a paper clip can climb up a ruler (either plastic or wood.) [Discuss with the students that magnets pull on magnetic materials, such as iron and steel, but pull through non-magnetic things, like cardboard, glass, plastic and wood, even water. Ask them why they think that this is the case.]

- Divide the students into pairs, and give each pair 40 inches of insulated wire, a large iron nail, sticky tape, scissors and a 1.5 -volt battery. Have them wind the insulated wire tightly around the nail 30 times, then use scissors to strip about $2 \mathrm{~cm}$ of plastic covering from both ends of the wire. Tape one end of the wire to the end of the battery marked + . Touch the opposite end of the battery with the other end of the wire. Now the electromagnet should be working. Test it on some paper clips. Take the wire off the battery. If the nail is made from pure iron, the paper clips will drop off slowly. If the nail contains some steel, it becomes a permanent magnet. [Ask the students if they know how hovering maglev trains -- like the ones in Japan -- work; if they don't know, ask them to postulate how electromagnetism could operate a train.]

- Have the students learn about the effect of electric charge or static electricity. Using two balloons, a nylon thread, sticky tape a soft and wooly scarf to rub on the balloons. Cut two equal lengths of thread and tape them to the top of a doorframe, spacing them about an inch apart. Tie one balloon to the end of each thread, so they are hanging at the same height. They should be touching. Ask the students to predict what will happen once they are both rubbed with the scarf. [Things made of the same material always take the same charge, so both balloons become negatively charged when you rub them. Matching charges of static electricity push each other away, like matching poles of magnets.]

"Proceedings of the 2003 American Society for Engineering Education Annual Conference \& Exposition Copyright C 2003, American Society for Engineering Education” 
- Challenge the students to make small pieces of tissue paper dance using a pencil, try to lead a ping pong ball across a table using a plastic comb, or make a small stream of flowing water bend using a pen. Have them guess what is happening. [Any charged object can temporarily charge something else (as long as that thing can hold a charge) in the same way as a magnet can make temporary magnets out of other metals. This is called induction.]

- Have the students make their own battery. Give the students a copper-coated and one zinccoated (galvanized nail, some thin, insulated wire, a compass and a container of salty water or watered-down vinegar. Coil the wire around the compass. Attach the compass to a flat surface, making sure the pointer is lined up with the coiled wire. Strip the insulation from the ends of the wire. Put the nails into the container with the salty water or vinegar. Watch out for movement in the compass needle. This shows if any electrical energy is being produced. Have the students predict what will happen if the nails are placed into a lemon, a potato, a glass of soda. Which makes the best battery? [The reaction, which takes place in the chemicals (salt or vinegar) in solution, releases electrical energy. This flows through the wire, creating a magnet field, which causes the needle to move.]

- Have the students make an electrical switch using a 4.5-volt battery, small light bulb and holder, paper clip, adhesive tape, electrical wires with plastic coverings, small piece of cardboard and 2 paper fasteners. Join the battery, bulb and three wires. Attach the wires to the battery using the tape. Push one paper fastener through the cardboard and hook a paper clip onto the second fastener and push this fastener through the cardboard. Turn the cardboard over and wrap one wire around each paper fastener. Bend the legs of the fasteners back and tape them down. Take the paper clip and press it onto the free paper fastener. Electricity should flow around the circuit. What happens to the light bulb? Now take the paper clip off the paper fastener. What happens to the light bulb this time? Why do you think this happens? [When you press the paper clip against the paper fasteners, you are joining up an electrical circuit. This enables electricity to flow around the wires and through the light bulb. This makes the bulb light up. When you break the connection you stop the electricity from flowing so the light stops shining.]

- Have the students discover the difference between a series or parallel battery set up. The students will need 3 fresh lemons, three 2 -inch pieces of $1 / 2$ inch copper tubing or two 6 inch pieces of bare copper wire from a hardware store, paper clips, aluminum foil, empty cereal box, scissors, and a liquid crystal display (LCD) clock, showing a black number on a gray background. Cut the cereal box into strips, and wrap aluminum foil around them. Stick one aluminum strip into each lemon with a paper clip on top. Stick one piece of copper into each lemon so that the copper and aluminum are close but not touching. For a series connection, attach the wires such that the aluminum in lemon \#1 to copper in lemon \#2, aluminum in lemon \#2 to copper in lemon \#3, aluminum in lemon \#3 to copper in lemon \#1, loose wires from aluminum in lemon \#1 and copper in lemon \#1. Now, hook the loose wires to the clock. Hook the wire from the copper to the plus side $(+)$ of the clock. Watch the clock. Have the students predict if the series or parallel battery arrangement will run the clock longer.

Simple algebraic formulas will be constructed around the activities. (Without electricity, you might be in the dark. What's the chance of selecting an AA battery that works from a drawer holding 15 batteries, only three of which are not dead on the first try?) Upon completion of these

\footnotetext{
"Proceedings of the 2003 American Society for Engineering Education Annual Conference \& Exposition Copyright $@$ 2003, American Society for Engineering Education"
} 
experiments, the Teaching Fellow would introduce an important algebraic concept used in engineering. In this case it would be Ohm's Law:

$\mathbf{V}=\mathbf{I} \cdot \mathbf{R}$

where $\mathbf{V}$ is voltage, $\mathbf{I}$ is current, $\mathbf{R}$ is resistance.

For more gifted students, the teacher may introduce Kirchhoff's voltage law.

$$
\sum_{\mathbf{j}=1}^{\mathbf{k}} \mathbf{V}_{\mathbf{j}}=\mathbf{0}
$$

The application of these equations to the set of experiments can be related to the Algebra/Data Analysis Content Standards sections 6.0, 7.0, 8.0, 9.0., and 10.0. This will be achieved by having the students analyze each of the experiments that were done, and identify how the Ohm's law (and Kirchhoff's law, if applicable) relates to each of the problems. All curricula will be developed to create a clear connection between the algebraic concepts and the engineering application as suggested below.

\begin{tabular}{|c|c|c|c|c|}
\hline $\begin{array}{l}\text { MSDE } \\
\text { Goal }\end{array}$ & Description & CD Kit & Learning Objective & $\begin{array}{l}\text { Evaluation } \\
\text { Method }\end{array}$ \\
\hline 6.0 & $\begin{array}{l}\text { Knowledge } \\
\text { of Number } \\
\text { Relationships } \\
\text { and } \\
\text { Computation }\end{array}$ & $\begin{array}{l}\text { Electricity } \\
\text { and Stored } \\
\text { Energy }\end{array}$ & $\begin{array}{l}\text { Calculation of terms in Ohm's (and } \\
\text { Kirchhoff's) law; understanding the } \\
\text { connection between and importance } \\
\text { of a variable and a "real world" } \\
\text { value. }\end{array}$ & $\begin{array}{l}\text { Experimental } \\
\text { observations, and } \\
\text { lab assignment, } \\
\text { assessment tool. }\end{array}$ \\
\hline 7.0 & $\begin{array}{l}\text { Process of } \\
\text { Problem } \\
\text { Solving }\end{array}$ & $\begin{array}{l}\text { Electricity } \\
\text { and } \\
\text { Stored } \\
\text { Energy }\end{array}$ & $\begin{array}{l}\text { Determine information needed or } \\
\text { missing to solve equations; look up } \\
\text { values of relative charge. Acquire } \\
\text { data, use a computational spreadsheet } \\
\text { to generate voltage vs. resistance } \\
\text { graphs; analyze results. }\end{array}$ & $\begin{array}{l}\text { Experimental } \\
\text { observations, use } \\
\text { of reference } \\
\text { materials, and } \\
\text { lab assignment. }\end{array}$ \\
\hline 8.0 & $\begin{array}{l}\text { Process of } \\
\text { Communicati } \\
\text { on }\end{array}$ & $\begin{array}{l}\text { Electricity } \\
\text { and Stored } \\
\text { Energy }\end{array}$ & $\begin{array}{l}\text { Analysis of observed results of the } \\
\text { experiments would be graphed to } \\
\text { give a visual display of observations. } \\
\text { Description of the reasoning process } \\
\text { predict/analyze each successive } \\
\text { experiment. }\end{array}$ & $\begin{array}{l}\text { Experimental } \\
\text { observations, lab } \\
\text { assignment and } \\
\text { pre-experiment } \\
\text { prediction. }\end{array}$ \\
\hline 9.0 & $\begin{array}{l}\text { Process of } \\
\text { Reasoning }\end{array}$ & $\begin{array}{l}\text { Electricity } \\
\text { and Stored } \\
\text { Energy }\end{array}$ & $\begin{array}{l}\text { Prediction of results of some } \\
\text { experiments based on previous } \\
\text { results. Give the students a flashlight } \\
\text { to take apart and demonstrate their } \\
\text { knowledge of the use and application } \\
\text { of Ohm's (and Kirchhoff's) law in } \\
\text { order to explain how a flashlight } \\
\text { works. }\end{array}$ & $\begin{array}{l}\text { Experimental } \\
\text { observation, lab } \\
\text { assignment, and } \\
\text { post experiment } \\
\text { analysis. }\end{array}$ \\
\hline 10.0 & $\begin{array}{l}\text { Process of } \\
\text { Connections }\end{array}$ & $\begin{array}{l}\text { Electricity } \\
\text { and } \\
\text { Stored }\end{array}$ & $\begin{array}{l}\text { Identify relationship between } \\
\text { numbers and graphed data. Identify } \\
\text { examples of electricity and how it }\end{array}$ & $\begin{array}{l}\text { Experimental } \\
\text { observations, lab } \\
\text { assignments and }\end{array}$ \\
\hline
\end{tabular}

"Proceedings of the 2003 American Society for Engineering Education Annual Conference \& Exposition Copyright $(2003$, American Society for Engineering Education” 


\begin{tabular}{|l|l|l|l|l|}
\hline & Energy & works in their everyday life. & $\begin{array}{l}\text { post experiment } \\
\text { analysis. }\end{array}$ \\
\hline
\end{tabular}

Prior to using the curriculum in the classroom, teachers will review each CD kit will be extensively. For instance, Loyola College in Maryland has an on-going mathematics teachertraining program designed to upgrade the skills of in-service teachers in the area of algebra and geometry. Class time in these training programs will be used to gather input from the teachers on all aspects of the materials prior to using them in the classroom. This feedback will be incorporated into the development of the product.

\section{Teacher Training}

The faculty team will present a five-day workshop to introduce the field of engineering to middle/high school mathematics teachers in order to help them encourage and prepare students for a career in the engineering profession. In this workshop, teachers will explore the spectrum and reach of engineering in society. Participants will also learn what a college engineering curriculum entails, including the mathematics requirements, and what makes students successful in engineering. Finally, teachers will be educated about those elements that would increase the interest of underrepresented groups in engineering as a career. Teachers will participate in the "hands on" engineering projects described in the CD kits.

The course will cover the following topics:

- An introduction to the broad field of engineering

- Opportunities and rewards of an engineering career

- Overview of the freshman engineering design course

- Student panel discussion on what it takes to be an engineering student

- Tour of UMBC's engineering facilities

- High school preparation for an engineering career, including math and science

- CD kit review, critique, and discussion for implementation in the classroom

- Engineering faculty panel discussion on various engineering disciplines

- Use of the Internet to learn about engineering

- "Hands on" projects to help introduce middle/high school students to engineering

- Engineering research pursuits

- Success strategies that students might use in their pursuit of an engineering career

- Issues and answers for encouraging females and other underrepresented groups to consider a career in engineering

The primary text for the course will be Studying Engineering A Road Map to a Rewarding Career by Raymond B. Landis. A typical day would involve an alumni panel, hands-on activity, review of after-school programs (such as Future Scientists and Engineers of America (FSEA) and Hands-On Science), success strategies for students, tours of engineering facilities, and methods of using the internet to extend engineering learning activities.

At the end of the workshop, each of the teachers will be required to incorporate the algebra/engineering curricula learned in the workshop into their classrooms. The teachers will then attend three additional follow-up days, one each semester and one the following summer, to help evaluate and revise the curricula. The teachers will also be asked to participate in a 
culminating event located at UMBC with their algebra students. An activity will take place in an engineering lab on campus to help students become familiar and comfortable with a university campus and understand the excitement and opportunities available in a course of study and career in engineering.

Through the workshop and the use of the CD kits, the teachers will gain a better appreciation of engineering and the kind of preparation needed for a career in engineering. Similarly, in the current project, there is opportunity for teachers to be exposed to current areas of research in engineering through presentations made by faculty during the summer workshops. These teachers will have the chance to tour labs of researchers and make connections for future research endeavors. The middle and high school students will also have an opportunity to view current engineering research when they tour the labs during the culminating activity. While there is no formal mechanism in place, both teachers and students are encouraged to develop relationships with the engineering faculty in order to become more aware of the types of things that engineers do. Middle and high school teachers can have a significant impact on a student's choice of career. By being given an awareness and appreciation for mathematics and engineering at an early age, students are more likely to choose higher-level mathematics and science courses that can better prepare them for college.

\section{Undergraduate Teaching Fellows Program}

Undergraduate engineering students will be selected and provided a stipend to support the program. Their responsibilities will include working with teachers during the summer workshop, supporting teachers in their initial implementation of the new curricula, and supporting the evaluation of the CD kits by gathering data from the students. They will also take a major role in the development of engineering after-school programs.

This program will build on the Integrate Teaching and Learning (ITL) program, an established K-12 engineering outreach program at the University of Colorado at Boulder. ${ }^{5,6}$ Students will be enrolled as Fellows as undergraduates in their sophomore and junior year to support increased retention. The program will particularly target women and other underrepresented groups to serve as Fellows to increase the diversity of role models in the schools. Students will be encouraged to enroll in pairs, as this increases the likelihood for their continued participation. ITL found that having two Fellows at one school works well. The student pairs will serve three schools each, deciding among themselves and the teachers during the summer workshop how best to provide the support needed. Some of the schools will already have after-school programs in place and will need less student support. The Teaching Fellows will gain a greater understanding of what they have learned in their engineering courses, improve their communication skills, and develop an appreciation for the educational process. Together these elements will enhance their retention.

\section{After-School Engineering Programs}

Once awareness of and interest in engineering is developed in the mathematics classes, many students may be interested in continuing to learn about engineering careers and participate in engineering-related activities. Locally, the Baltimore Museum of Industry, host of the Maryland Engineering Challenges, provides an introduction to many fields of science, mathematics, engineering, and technology through rewarding and age-appropriate problem-solving activities.

\footnotetext{
"Proceedings of the 2003 American Society for Engineering Education Annual Conference \& Exposition Copyright $₫$ 2003, American Society for Engineering Education”,
} 
The Engineering Challenges in Maryland have evolved from a number of different initiatives from groups of engineers, educators, and people involved in the Baltimore Museum of Industry. Middle school students might build powered maglev models, straw bridges or a model hovercraft. Additionally, high schools students might be invited to design and build a wood bridge, robot, miniature cargo aircraft or model ship. The Engineering Challenge Series is sponsored by the Engineering Society of Maryland, the Technology Association of Maryland, and the National Aeronautics and Space Administration (NASA). Other opportunities involve the FSEA organization which provides science and engineering activities for middle school students. The Teaching Fellows will take a lead role in building these after-school programs.

\section{Participation of Women and Other Underrepresented Groups}

The September 2000 Report of the Congressional Commission on the Advancement of Women and Minorities in Science, Engineering and Technology Development (CAWMSET) stated that "Unless the SET (science, engineering and technology) workforce becomes more representative of the general U.S. workforce, the nation may likely face severe shortages in SET workers. Yet, if women, underrepresented minorities and persons with disabilities were represented in the SET workforce in parity with their percentages in the total workforce population, this shortage could largely be ameliorated." One recommendation the Commission presented was the development of high quality mathematics and science curricula for the pre-college environment, developed at the state level. Additionally, the Commission recommended teachers be well-prepared to teach that curricula.

The Teaching Fellows and teachers will receive training to insure they support a climate for young women and other underrepresented groups while addressing the major barriers to learning that most often affect girls, but also have an impact upon other underrepresented groups. ${ }^{8}$ The curriculum will address motivational barriers by providing a simple yet interesting and fun application of mathematics to help motivate all students. Unequal background preparation will be leveled by teaching mathematics in an engineering context while developing mathematical methods and other skills as the course progresses. Lack of social usefulness can be addressed by providing projects that show the connection of mathematics to engineering applications that are in turn connected to everyday household objects. All CD kits will be developed with a module that highlights successful engineers from a diversity of backgrounds.

\section{EVALUATION AND DISCUSSION}

All curricula developed by the project will be assessed using feedback from the teachers who have been trained to use the curricula, teachers who have taught using the curricula, and the students who participated in the learning process. The information gathered will support modifications in the training of teachers and content of the educational materials. Further, teachers who have participated in the workshop will be interviewed to find out what they find to be useful about the educational materials, and any suggestions they have for improving the usability of the materials. They also will be asked for input about how the education of teachers might be improved. Finally, they will be asked how they specifically intend to incorporate the educational materials into their instruction. Teachers who have used the educational materials will be interviewed about their experience with the materials, and suggestions for improvement

\footnotetext{
"Proceedings of the 2003 American Society for Engineering Education Annual Conference \& Exposition Copyright $₫$ 2003, American Society for Engineering Education”,
} 
regarding the materials and training program will be obtained. These research activities will be designed to evaluate the project with reference to objectives 1 and 2 .

Another element of the evaluation will be the completion of a survey and interviews of the Fellows for subjective information about their enjoyment of the project, the identification of learning that has taken place, and their own understanding and appreciation of engineering in relation to education. A final element of the evaluation will be to observe whether student activities under objectives 4 and 5 are implemented. Evaluation for these objectives also will involve administration of questionnaires and/or interviews to students participating in the programs regarding desirable and undesirable characteristics of program activities.

The evaluation summary will use the results from several assessment strategies to determine if student outcomes have been achieved. The primary student outcomes are program participation and interest in engineering (including intentions to continue in the subject area), particularly among females and other underrepresented groups. Program participation will be measured by strategies such as sign-in sheets and direct observation. Direct observation will permit ratings of amount and quality of participation beyond mere attendance. Interest and intentions will be assessed by interview and questionnaire methods. This assessment will take place at the end of the students' participation in the program (i.e., at the end of the semester or year). With the help of the teachers, students will also be tracked to identify whether they take additional advanced mathematics courses, passed the high school assessment for algebra/data analysis on the first or subsequent attempts, and/or participate in an engineering after-school program. This data will be compared to students in algebra classes that did not use the curriculum.

1. Before It's Too Late: A Report to the Nation from the National Commission on Mathematics and Science Teaching for the 21st Century. 30 Apr. $2002<\mathrm{http}: / /$ www.ed.gov/americacounts/glenn/toolateexecsum.html $>$.

2. Massachusetts Science and Technology/Engineering Curriculum Framework. Massachusetts Department of Education. May 2001.

3. Mooney, M. and T. Laubach. Adventure Engineering: A Design Centered, Inquiry Based Approach to Middle Grade Science and Mathematics Education. Journal of Engineering Education. 91(3):309-318.

4. Symans, M. Introducing Middle School Students to Engineering Principles Using Educational Bridge Design Software. Journal of Engineering Education. 89(3):273-278.

5. DeGrazia, J., J. Sullivan, L. Carlson, D. Carlson. A K-12/University Partnership: Creating Tomorrow's Engineers. Journal of Engineering Education. 90(4):557-563.

6. Poole, S., J. Degrazia, and J. Sullivan. Assessing K-12 Pre-Engineering Outreach Programs. Journal of Engineering Education. 90(1):43-48.

7. "Land of Plenty: Diversity as America's Competitive Edge in Science, Engineering and Technology." Report of the Congressional Commission on the Advancement of Women and Minorities in Science, Engineering, and Technology Development. September 2000.

8. Rosser, S., ed. Teaching the Majority: Breaking the Gender Barrier in Science, Mathematics, and Engineering. New York: Teachers College, 1995.

"Proceedings of the 2003 American Society for Engineering Education Annual Conference \& Exposition Copyright $\bigcirc$ 2003, American Society for Engineering Education” 
ANNE SPENCE holds a Ph.D. in Aerospace Engineering and is a lecturer in the Department of Mechanical Engineering at UMBC. During her eight years as an engineering educator, she has developed curricula, directed programs to increase the recruitment and retention of women in engineering, and developed hands-on engineering programs designed to foster an interest in engineering among elementary, middle and high school students.

TARYN BAYLES holds a Ph.D. in Chemical Engineering and is a lecturer in the Department of Chemical/Biochemical Engineering at UMBC. She emphasizes practical applications from her industrial experience when teaching engineering courses. Most recently she developed, coordinated and taught a summer workshop, "Introduction to Engineering for High School Teachers and Counselors."

CLAUDIA MORRELL, Director of Planning and Grants for the Center for Women and Information Technology at UMBC, joined the University in August of 2001. In both this and her previous position at CCBC, she became familiar with and has worked to address the issues related to the lack of participation of girls and women in STEM programs. Her skills as a collaborator have been instrumental in building bridges between the two institutions. 